INSTITUTE OF FORESTRY • BELGRADE

INSTITUT ZA ŠUMARSTVO • BEOGRAD

SUSTAINABLE FORESTRY

COLLECTION 73-74, 2016
ODRŽIVO ŠUMARSTVO

ZBORNIK RADOVA 73-74, 2016

UDK $630 * 272+632(497.11)=111$

UDK 635.054+632(497.11) $=111$

Original scientific paper

\title{
THE COMPARATIVE ANALYSIS OF THE STATE OF DENDROLOGICAL PLANTS IN BELGRADE PARKS, SERBIA
}

\author{
Tatjana ĆIRKOVIĆ-MITROVIĆ, Ljiljana BRAŠANAC-BOSANAC, \\ Katarina MLADENOVIĆ, Ivan MILENKOVIĆ ${ }^{1}$
}

\begin{abstract}
This paper presents the results of the conducted research of the health status and seed yield of the dendrological species in five parks situated in areas with different degrees of pollution. According to the volume of seed yield, selected trees in SIV Park had the lowest yield, somewhat higher yield were displayed by the trees in Banovo Brdo Park, then Pioneer Park and Topcider Park, whereas the most abundant yield was that of the trees in Academic Park. On the other end, as per visual assessments of the health state, the trees in Pioneer Park showed the best health condition, the second best had the trees in SIV Park (air pollution zone), then the trees in Topcider Park and Banovo Brdo Park, while the lowest average score was assigned to the trees in Academic Park. Results of the conducted research suggest that the condition of dendrological plants in these parks is significantly dependent in the protection and care measures taken.
\end{abstract}

Key words: parks, Belgrade, health status of trees, seed yield of trees.

\section{UPOREDNA ANALIZA STANJA DRVENASTIH BILJAKA U PARKOVIMA BEOGRADA, SRBIJA}

\begin{abstract}
U$ radu su prikazani rezultati istraživanja zdravstvenog stanja $i$ obilnosti uroda drvenastih biljaka u pet parkova koji se nalaze u uslovima različitog stepena zagađenosti. Prema obilnosti uroda najmanji urod imala su izabrana stabla $u$ parku SIV, zatim u parku Banovo brdo, Pionirskom parku, Topčideru, a najbolji urod stabla u Akademskom parku. Prema vizuelnoj oceni zdravstvenog stanja najbolja su stabla u Pionirskom parku, zatim parku SIV (zona sa zagađenim vazduhom), Topčiderskom parku, parku Banovo brdo, a najnižu prosečnu ocenu imala su stabla u Akademskom parku.
\end{abstract}

\footnotetext{
${ }^{1}$ Institute of Forestry, Kneza Viseslava 3, 11030 Belgrade, Serbia
} 
Rezultati istraživanja ukazuju da stanje drvenastih biljaka u ovim parkovima značajno zavisi od mera nege koje se sprovode.

Key words: parkovi, Beograd, zdravstveno stanje stabala, obilnost uroda stabala.

\section{INTRODUCTION}

Urban parks have a strategic importance for quality of life in our urbanizing society and play a significant role in increasing the livability of cities (Biddulph, 1999). Within the complex of environmental factors through the mutual plant/man impact, depending on whether their interplay leads to enhanced and progressive environment, parks are priceless to a sustainable urban development. In environmental terms, urban areas are specific to the survival and development of plants due to various adverse conditions typical of such areas (small quantities of water, restricted space for root system growth, air pollutants, etc.). Therefore monitoring of the condition of dendrological plants in parks is of a great significance since determining the health status and seed yield enables recommending implementation of appropriate protection and care measures to the park plants.

\section{MATERIAL AND METHOD}

The relevant parks were selected according to their locations in Belgrade. Parks in the very downtown Belgrade were selected (Academic Park and Pioneer Park) as well as those at the rim of the central urban area (SIV and Banovo Brdo) and one in the forest park area (Topčider Park).

The selected parks are situated in in areas with different degrees of pollution, in the following zones (Aničić Urošević et al., 2015):

- Pioneer Park - in a zone with high air pollution and traffic flow of above 3,500 vehicles per hour;

- SIV Park - in a zone with air pollution and traffic flow of 2,000 to 3,000 vehicles per hour;

- Banovo Brdo Park and Academic Park - in zones with moderate air pollution and traffic flow of 1,000 to 2,000 vehicles per hour;

- Topčider Park - in a zone with low air pollution and traffic flow of below 1,000 vehicles per hour. 


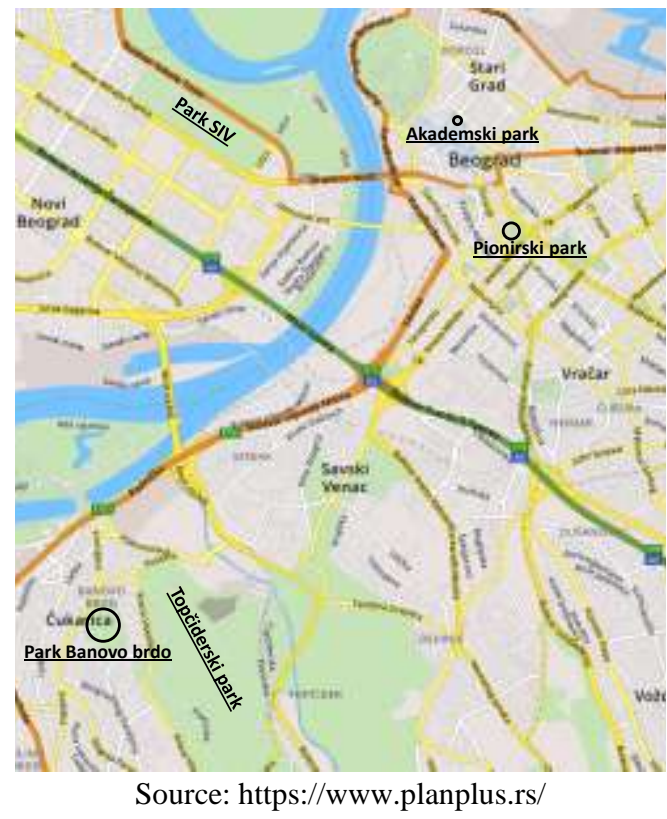

Figure 1. Location of parks in Belgrade

Species and individual plants were selected according to the share of the specific species in the total number of trees in the parks under observation. The number of selected trees per species differed from one park to another, depending primarily on their share in the total number of trees in the relevant park. The trees subject to research totaled 37 in Pioneer Park, 15 in Academic Park, 29 in Banovo Brdo Park, 37 in SIV Park and 17 in Topčider Park. The aggregate number of trees selected and assessed counted $135-72$ coniferous and 63 deciduous trees.

During vegetation in the years 2015/16 all trees in the aforesaid Belgrade parks were examined in in order to evaluate the general condition of the tree species.

Analyses of the seed yield and its volume were performed using the adapted Kaper scale for forecasting seed yield within a stand (Stilinović, 1985, Isajev et. al., 1998) (Table 1).

Table 1. Yield scoring scale

\begin{tabular}{|lc|c|}
\hline \multicolumn{2}{|c|}{$\begin{array}{c}\text { Category of yield } \\
\text { volume }- \text { score }\end{array}$} & Quantitative yield volume parameters \\
\hline $\mathbf{0}$ & - & No fruit \\
\hline $\mathbf{1}$ & Very poor & Insignificant number of fruits in trees \\
\hline $\mathbf{2}$ & Poor & Small number of fruits in trees \\
\hline $\mathbf{3}$ & Medium & More observable fruits in trees \\
\hline $\mathbf{4}$ & Good & Sufficient fruits in trees \\
\hline $\mathbf{5}$ & Very good & High volume of fruits in trees \\
\hline
\end{tabular}

The examination of the health of trees involved detection of mechanical, phytopathological, entomological and acarological damages to the tree crowns, tree trunks and root collar zone. 
Fieldwork was conducted twice during a single vegetation period, in spring and in summer. Biotic and abiotic damages were identified in all trees. In order to determine the as-is health condition of trees and identify any health impairing factors, visual assessments of health status and of assimilation area loss and discoloration were made for the trees under observation. In June and July defoliation was assessed, while discoloration was inspected in the observed trees in August, applying ICP Forests methodology (Anonymous, 2006; 2010).

Visual assessment of the health of trees was provided for all trees under observation according to the scale presented in Table 2 .

Table 2. Scale for the visual assessment of the health status of trees

\begin{tabular}{|cc|c|}
\hline \multicolumn{2}{|c|}{$\begin{array}{c}\text { Visual assessment of the } \\
\text { health of trees }\end{array}$} & Quantitative parameters \\
\hline $\mathbf{1}$ & Dead tree & - \\
\hline $\mathbf{2}$ & Tree dying out & $\begin{array}{c}\text { significantly reduced leaf assimilation area, progressive rot } \\
\text { in trees and branches, poses a public safety issue }\end{array}$ \\
\hline $\mathbf{3}$ & $\begin{array}{c}\text { Tree with } \\
\text { significant } \\
\text { damage }\end{array}$ & $\begin{array}{c}\text { presence of damage to the foliage, trunk and branches with } \\
\text { possibility of recovery, tip burns, rot in trunk and/or } \\
\text { branches }\end{array}$ \\
\hline $\mathbf{5}$ & $\begin{array}{c}\text { Tree with minor } \\
\text { damage }\end{array}$ & $\begin{array}{c}\text { rare and random damage to the foliage, trunk and branches, } \\
\text { with a small number of dry branches }\end{array}$ \\
\hline $\mathbf{5}$ & Healthy tree & $\begin{array}{r}\text { without visible symptoms of damage to the foliage, trunk } \\
\text { and branches, or with insignificant damage }\end{array}$ \\
\hline
\end{tabular}

Young, newly planted trees were exempt from the assessment of the health status, with remarks recorded on any abiotic and/or biotic damages present.

The data processing and analyses were done in Microsoft Office Excel 2007 and Statistica 7 statistical software application.

\section{RESULTS AND DISCUSSION}

In the parks under observation there were neither dead trees nor those assigned score 1 among the selected trees, whereas only two were classified into score 2 category. These two trees bore no fruits. Graph 1 presents the average scores for seed yield volume (abundance) against the assessed health status with a 0.95 confidence interval for all parks under observation. The best health status-toyield ratio was exhibited by the trees assigned score 3 for the health status (presence of damage to the foliage, trunk and branches with possibility of recovery, tip burns, rot in trunk and/or branches). 


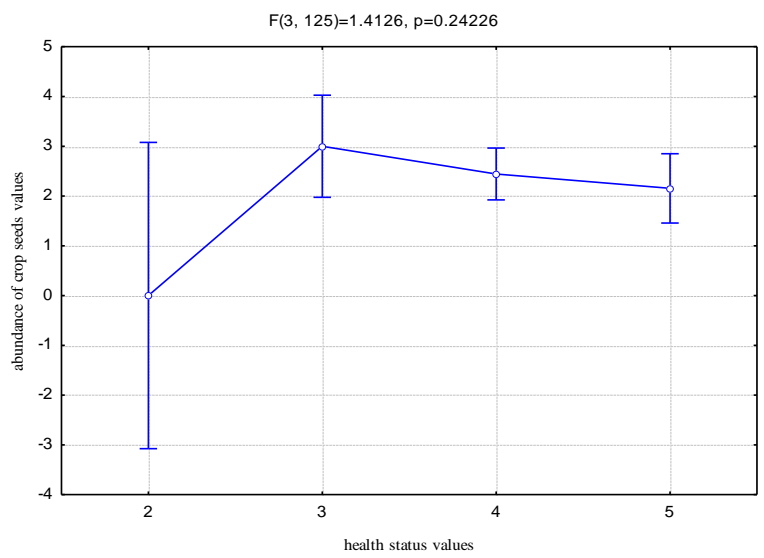

Graph 1. Average scores for the volume (abundance) of seed yield against the assessed health status with a 0.95 confidence interval

Trees dying out (birch and European yew trees) were identified only in Banovo Brdo Park, with significantly reduced leaf assimilation area and progressive rot in trees and branches. These trees bore no fruits. Trees assigned scores 3, 4 and 5 had poor to medium seed yield on the average.

When observed at the individual park level in terms of the worst and best health status trees (Graph. 2a-e), it was found that in Pioneer Park spruce and Douglas fir trees with significant injuries bore no fruits, small-leaved lime trees had good yield, while a single European yew tree and two horse chestnuts had very good yield. Among the trees with the same health status in Academic Park, one horse chestnut scored 3 for yield, while one horse chestnut, cedar and small-leaved lime each scored 5.

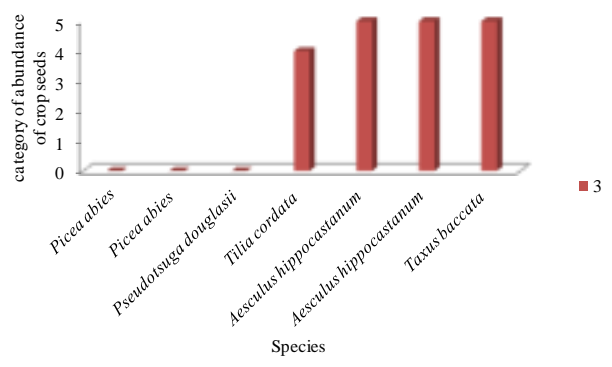

Visual evaluation the health status 3

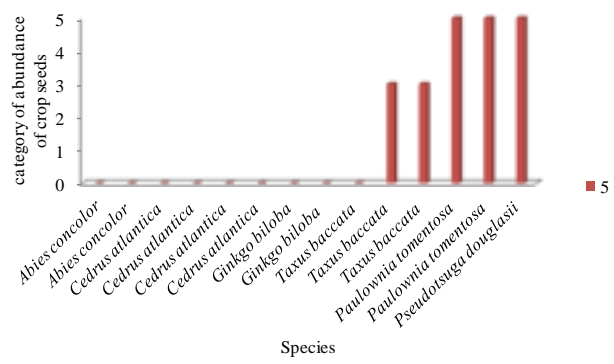

Visual evaluation the health status 5

a) Pioneer Park 


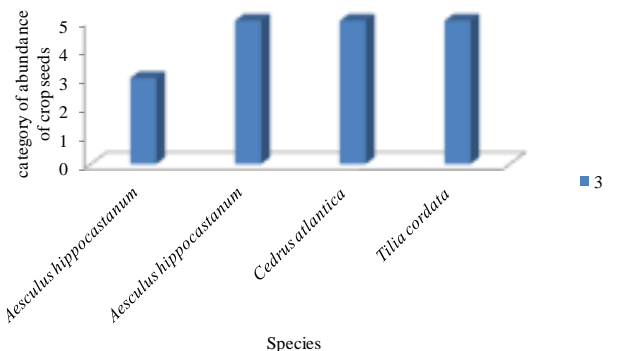

Visual evaluation the health status 3

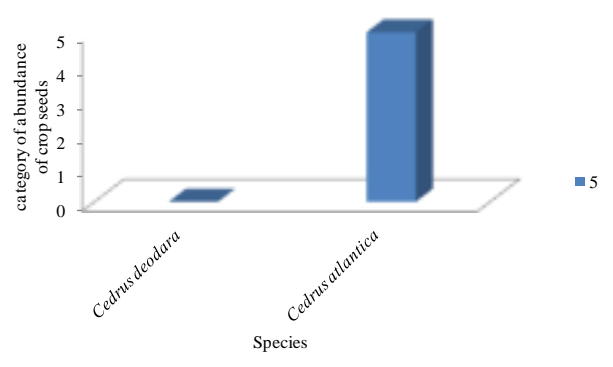

Visual evaluation the health status 5

b) Academic Park

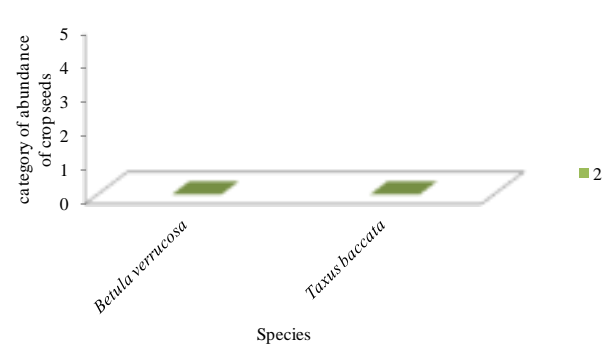

Visual evaluation the health status 2

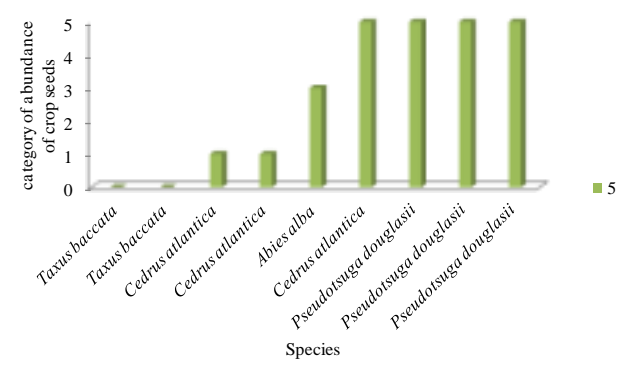

Visual evaluation the health status 5

c) Banovo Brdo Park

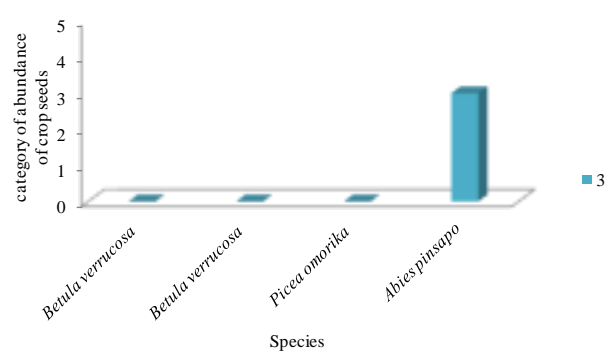

Visual evaluation the health status 3

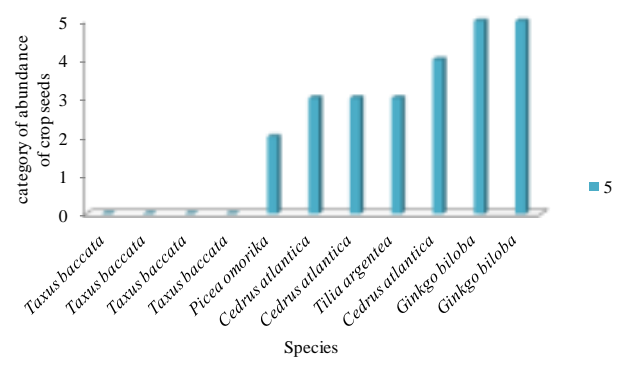

Visual evaluation the health status 5

d) SIV Park

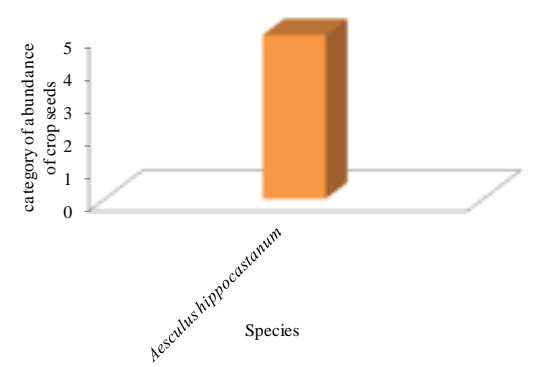

Visual evaluation the health status 3

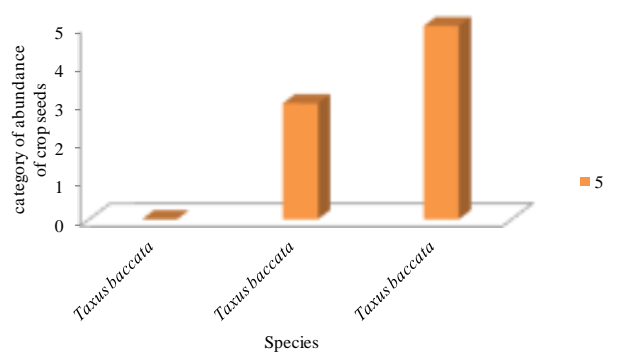

Visual evaluation the health status 5

e) Topčider Park

Graph 2(a-e). Seed yield of trees with different health status scores 
In Banovo Brdo Park two trees in health status category 2 bore not fruits, while in SIV Park two birch trees and one Serbian spruce in health status category 3 had no yield, while a single Spanish fir scored 3 for seed yield (medium yield). In Topčider Park a chestnut tree with score 3 for the health status had very good seed yield.

Of all healthy trees assessed, in Pioneer Park two European yew trees scored 4 for seed yield and two paulownias and one Douglas fir had very good yield (score 5). Other trees (white firs, Atlas cedars, gingko and European yew trees) were not fruit-bearing. In Academic Park, a healthy Himalayan cedar bore no fruits, while an Atlas cedar had very good yield (score 5). In Banovo Brdo Park European yew trees bore no fruits, Atlas cedars had very poor and firs had medium seed yield. One Atlas cedar and three Douglas firs had good seed yield. In SIV Park European yew trees bore no fruits, while a Serbian spruce had poor yield. Somewhat better yield was recorded in two Atlas cedars and a small-leaved lime. Another Atlas cedar had good, while two gingko trees had very good yield. The three European yew trees selected for analysis in Topčider Park were all assigned different scores for see yield - one bore no fruits, and the other two had medium and very good seed yield volume.

\section{CONCLUSIONS}

According to the seed yield volume (abundance) the lowest score was achieved by the trees selected in SIV Park, the second lowest were those in Banovo Brdo, third highest seed yield volume was recorded in Pioneer Park, second in Topčider, and the highest was recorded in Academic Park (average seed yield score of 3.4).

As per visual assessment of the health status, trees in Pioneer Park displayed the best health although this park is located in a zone with very high air pollution. Trees in SIV Park (a zone with air pollution present) had the second best health status, then came the trees in Topčider Park and Banovo Brdo, while the lowest average score per health status criterion was achieved by the trees in Academic Park.

The green areas analyzed differ in the number of trees observed and environmental conditions, yet it can be remarked that their general condition is largely dependent on the protection and care measures implemented in parks. This is supported by the high scores achieved by trees in the downtown Belgrade, although the downtown area is exposed to the high traffic flow and frequency. Good examples are Pioneer Park, which is located in a zone with high air pollution and Academic Park, categorized as a significant natural asset with third degree protection regime set up since 2007 .

\section{ACKNOWLEDGMENTS}

This paper is a result of research carried out within the Project "Development of Technological Methods in Forestry in order to Attain Optimal Forest Cover" (TR 31070, led by Dr. Ljubinko Rakonjac) financed by the Ministry of Education, Science and Technological Development of the Republic of Serbia and "Morphological-Anatomic and 
Physiological Changes in Dendrological Species in Belgrade Parks as Indicators of the State of the Environment" (led by Dr. Ljubinko Rakonjac, coordinated by Dr. Baranislava Batos), financed by the City of Belgrade, City Administration, Secretariat for Environmental Protection.

\section{REFERENCES}

Anonymus (2006): Visual assessment of crown condition - Manual on methods and criteria for harmonized sampling, assessment, monitoring and analysis of the effects of air pollution on forests, International Co-operative Programme on the Assessment and Monitoring of Air Pollution Effects on Forests, Hamburg

Anonymus (2010): Visual assessment of crown condition and damaging agents -Manual on methods and criteria for harmonized sampling, assessment, monitoring and analysis of the effects of air pollution on forests, Part IV, International Co-operative Programme on the Assessment and Monitoring of Air Pollution Effects on Forests, Hamburg

Biddulph, M. (1999): Bringing Vitality to a Campus Environment. Urban Design Int., 4(3\&4), 153-166

Isajev, V., Čomić, M., Mančić, A., Mataruga, M. (1998): Priručnik za proizvodnju šumskog semena u prirodnim semenskim objektima, Banja Luka 3-64 Stilinović, S. (1985): Semenarstvo šumskog i ukrasnog drveća i žbunja, Šumarski fakultet Beograd

Aničić Urošević, M. et al. (2015): Biomonitoring teških metala u vazduhu / edukacija o uticaju saobraćaja na kvalitet vazduha, Izveštaj, Institut za fiziku, Beograd. 